\title{
Children's Genomic Instability in Association with Balance of the Autonomous Nerve System Departments
}

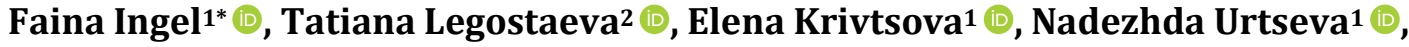

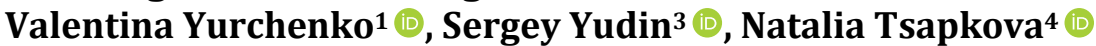

\begin{abstract}
${ }^{1}$ Laboratory of Genetic Toxicology of Federal State Budgetary Institution, "Center for Strategic Planning and Management of Medical and Biological Health Risks", Russian Ministry of Health, Moscow, Russia

${ }^{2}$ Municipal Educational Institution, “Secondary School No. 5 with Advanced Study of Mathematics” of the Magnitogorsk. Magnitogorsk, Russia

${ }^{3}$ Federal State Budgetary Institution, “Center for Strategic Planning and Management of Medical and Biological Health Risks", Russian Ministry of Health, Laboratory of Genetic Toxicology, Moscow, Russia

${ }^{4}$ Department of Epidemiology and Evidence-Based Medicine of I.M.Sechenov First Moscow State Medical University, Moscow, Russia

Email: ^fainaingel@mail.ru, ^FIngel@cspmz.ru
\end{abstract}

How to cite this paper: Ingel, F., Legostaeva, T., Krivtsova, E., Urtseva, N., Yurchenko, V., Yudin, S., \& Tsapkova, N. (2019). Children's Genomic Instability in Association with Balance of the Autonomous Nerve System Departments. Psychology, 10, 2026-2037.

https://doi.org/10.4236/psych.2019.1015130

Received: November 11, 2019

Accepted: December 17, 2019

Published: December 20, 2019

Copyright $\odot 2019$ by author(s) and Scientific Research Publishing Inc. This work is licensed under the Creative Commons Attribution International License (CC BY 4.0).

http://creativecommons.org/licenses/by/4.0/ (c) (i) Open Access

\begin{abstract}
This article presents new results of the investigation of anxiety and balance of the departments of autonomic nervous system of 178 healthy $5-7$ years old children living in 2 different districts of Magnitogorsk town. It is shown that the state of increased and high anxiety more often was detected among children living around the Magnitogorsk Iron and Steel Combine (MISC). Among these children, an imbalanced work of the departments of autonomic nervous system (mostly ergotropic tone) found out more often than among children, living in the other district of the town. The increased genome instability as well as individual sensitivity of children's genome to standard genotoxic load determined in vitro in peripheral blood cultures (micronucleus test with Cytochalasin B) correlated with children's psychosomatic characteristics, especially for those who lived around the MISC.
\end{abstract}

\section{Keywords}

Children of 5 - 7 Years, Anxiety, Balance of the Departments of Autonomous Nervous System, Genomic Instability, Micronuclei Test with Cytochalasin B

\section{Introduction}

Many modifying effects complicate an identification of risk factors to human 
health. For example, a severity of emotional stress modifies the processes of DNA damaging and reparation which directly related to carcinogenesis (Seredenin, Durnev, \& Vedernikov, 1980; Ingel, 2006; Markkanen, Meyer, \& Dianov, 2016; Bergholz et al., 2017; Fink, 2019). For people in the state of emotional disadaptation, the genome sensitivity to genotoxic compounds-mutagens and/or carcinogens increases (Ingel, 2006; Ingel et al., 2010, 2018). These data proved the necessity of taking into consideration the severity of emotional stress expression (especially for children-as alarm reaction) during environmental health studies.

The approach grounded on the complex of genetic and psychological studies has proved to be very effective in analyzing the causes of genetic damage induction. The psychological reactions that are taken into account earlier are mainly related to the reaction of the Central nervous system. In the subsequent development of these studies, we suggested that the state of the autonomic nervous system (the type of balance between sympathetic and parasympathetic departments-vegetative balance) could also be associated with various factors of genome instability. If this hypothesis is correct, the new direction of study of the consequences of vegetative balance variability will be discovered. In literature, such approach and data are absent.

Vegetative disorders (VD), representing the ultimate case of the unbalance between the departments of autonomic nervous system (ANS) and significantly affecting human behavior, are one of the urgent problems of modern medicine because of their high prevalence, including among people considering themselves to be healthy (Alexander, 1950; Wein, 1998; Zlobina., Shinkarenko, \& Maslova, 2004). There are practically no pathological forms in the development and course of which the ANS would not play a role, but the real cause of the diseases becomes much less common. Therefore, VD are different variants of primary functional autonomic dysfunction, not associated, however, with any particular disease. It is important that VD almost occurs as a reaction of the human body to stress within the physiological, that is, normal, reaction (Alexander, 1950; Wein, 1998; Zlobina, Shinkarenko, \& Maslova, 2004).

VD are more common among children, adolescents and young people, which is usually associated with a disproportion in the development of executive bodies and/or the apparatus of regulation of their activities (Alexander, 1950; Wein, 1998; Zlobina, Shinkarenko, \& Maslova, 2004). For the development of VD, the features of child upbringing that lead to a mismatch of mental and physical development, as well as social and environmental problems, noise, vibration, gas pollution, physical and emotional overload and stressful situations are also important (Wein, 1998; Pocock, 2006; Veenstra, Luginaah, Wakefield et al., 2005).

The aim of this study, carried out in Magnitogorsk-the large industrial center of ferrous metallurgy, was to analyze the associations between severity of alarm, balance of the departments of autonomic nervous system and genome instability of children living permanently in the city. 


\section{Materials and Methods}

The term "genomic instability" describes complex of various molecular mechanisms and their effects leading stable genome of normal cell to unstable, characteristic for tumors (Smith et al., 2003).

This study was carried out in Magnitogorsk city, which regularly includes in the "Complete list of 35 the most polluted cities in the world", compiled annually by the Blacksmith Institute (Ural'shin et al., 2007, Antipanova \& Koshkina, 2007). The city-forming enterprise is Magnitogorsk Iron and Steel Combine (MISC) with full metallurgical cycle. The Ural River subdivides the city into 2 parts-Left Bank, where MISC is located, and Right Bank (Figure 1). Since 1995, the constant increase of number of oncologic diseases in the city, especially among children and people of reproductive age is detected. Some authors traditionally associate this situation with negative impact of MISC atmospheric emissions (Ingel et al., 2010). We supposed that environmental pollution could increase the manifestation of the weak associations and/or properties undetectable under other conditions, but which may be manifested in future as significant negative health effects.

Cohort formation: in 6 municipal kindergartens located both on the Right and Left banks of the Ural River (Figure 1), chose healthy children of 5 - 7 years old by the following criteria:

- Parents of these children did not work in the MISC hazardous departments before the child conceiving;

- Children at the time of examination had no chronic diseases and congenital malformations and within 2 months prior to the study did not receive medicinal and other types of therapy and surgical interventions;

- Children attended kindergartens, located near the house, at least 3 years in a row.

Selected 178 children as well as their parents became participants of the study.

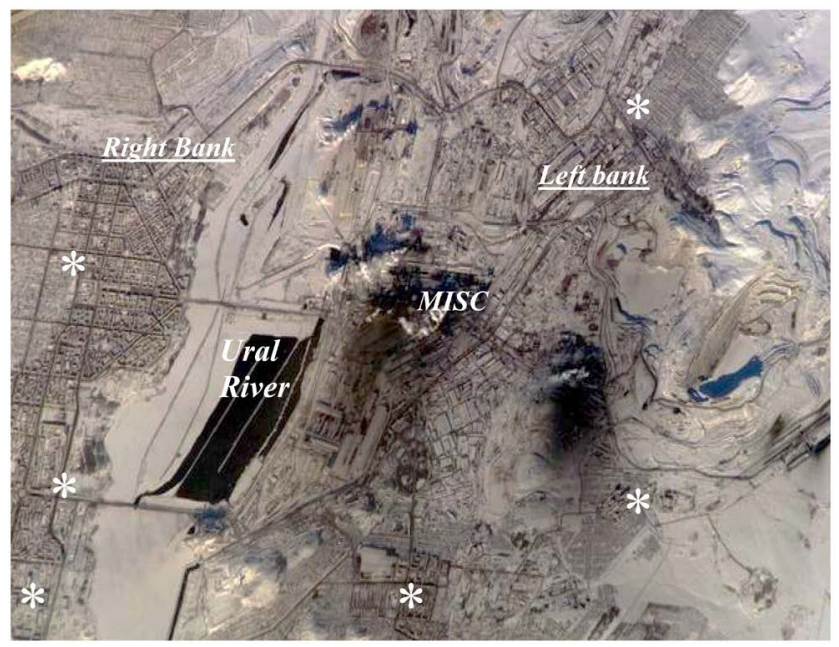

Figure 1. Winter magnitogorsk. Photo from satellite. The kindergartens location marked as asterisks. 
Children's anxiety and the coefficient of vegetative balance (Shiposh coefficient) were determined in 8-color M. Luscher's test (Sobchik, 2003; Dragunsky, 2004). The method reveals not so much the conscious subjective attitude of the subject to the color standards, as his unconscious reactions, which allows us to consider the method deep and projective (Sobchik, 2003).

Analysis of instability and individual sensitivity of children's genome carried out in the cytogenetic micronucleus test using whole venous blood, cultivated under cytokinetic block conditions (Bolognesi \& Fenech, 2019; Nersesyan et al., 2016). $1 \mathrm{ml}$ blood tock out under sterile conditions from each child (this work carried out procedural nurses in the premises of the city children's clinical hospital of Magnitogorsk). For each child, 2 parallel phials with blood cultures were used to determine the spontaneous (background) level and in vitro individual genome sensitivity to the small genotoxic load using standard direct-acting mutagen N-methyl-N-nitro-N-nitrosoguanidine (MNNG). This compound to the final concentration of $0.07 \mathrm{mM}$ (Slamenová et al., 2003) injected into one of the 2 phials at 24 hours from culture setting. At the same time into another culture from each child the same volume of physiological solution was injected. At 44 hours from the start of culture setting the Cytochalasin B $(6 \mathrm{mkg} / \mathrm{ml})$ was injected into each phial for cytokinetick block creation. Cells in each phial were fixed at 72 hours after the beginning of the cultivation (Bolognesi \& Fenech, 2019; Nersesyan et al., 2016).

Microscopic cytome analysis carried out in accordance to (Ingel, 2006; Bolognesi \& Fenech, 2019; Nersesyan et al., 2016). The main types of cells which was take into account during cytome analysis presents on Figure 2.

Totally it was analyzed more than 196,000 cells.

Statistical analysis carried out using the Statistica 10.2 (Statsoft) standard package. The nonparametric Mann-Whitney criterion (z), had been used for comparisons. Spearman's criterion (R) was used to analysis of correlations.

The study was carried out in frames WMA Declaration of Helsinki-ethical principles for medical research involving human subjects (1964-2008) with the permission of the Magnitogorsk' Main Pediatrician and the written informational consent of parents of all children selected for the examination.

\section{Results}

The results of children's psychological testing showed that the severity of anxiety as well as balance of ANS departments (Shiposh' coefficient) in both districts of Magnitogorsk were within the accepted normal intervals and did not differ in average values (Table 1 ).

At the same time, the state of vegetative balance was associated with anxiety expression (Figure 3). We saw that the high level of anxiety expression was associated with significant misbalance in work of the ANS departments. Because it is known that the high level of anxiety is connected with increased genome sensitivity to environmental genotoxicants, this result allows think that the individual or group characteristic of the vegetative balance may give new further information 


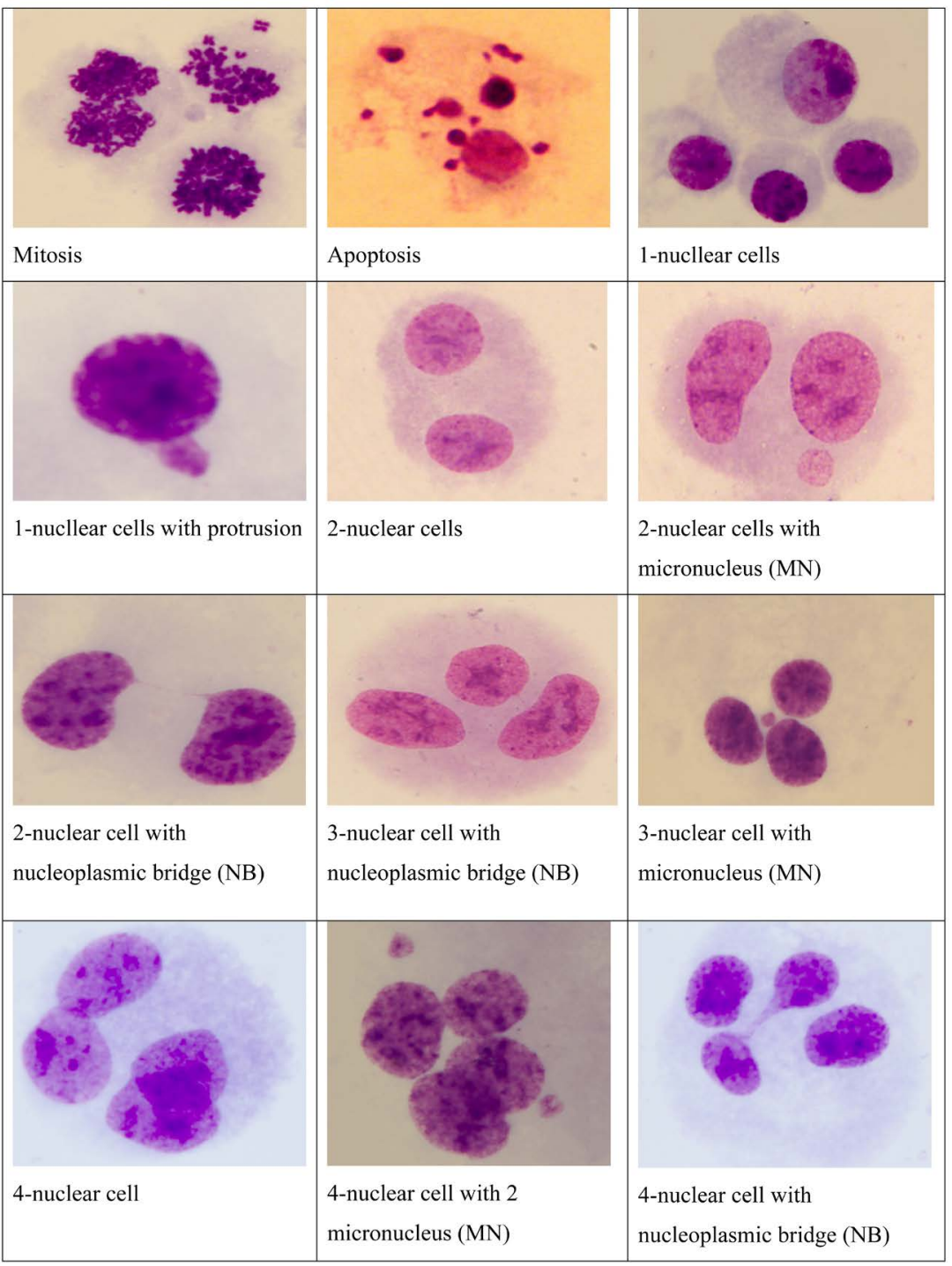

Figure 2. Micrograph of the main typical cytogenetic objects for genomic instability detection. Microscope Leica 5000M, Visible light. $10 \times 100$, oil immersion.

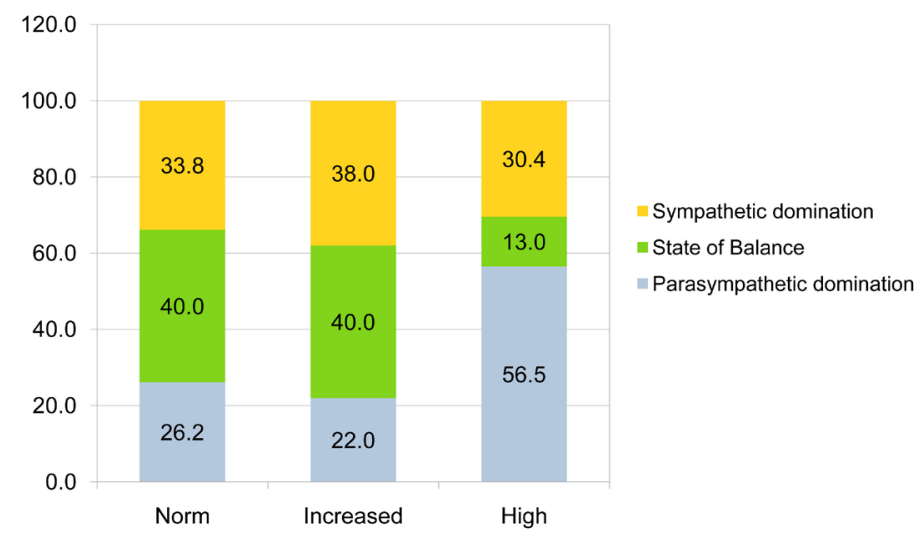

Figure 3. Proportions of children with different vegetative balance depending on their anxiety expression (\%). Axis-portion of children cohort with different state of vegetative balance (\%). 
Table 1. Anxiety expression and balance of the departments of autonomous system in children from different districts of Magnitogorsk (by M. Luscher's test, average levels).

\begin{tabular}{ccccc}
\hline & \multicolumn{2}{c}{ Complete family } & \multicolumn{2}{c}{ Incomplete family } \\
\cline { 2 - 5 } Index & $\begin{array}{c}\text { Right bank } \\
\mathrm{M} \pm \mathrm{m}\end{array}$ & $\begin{array}{c}\text { Left bank (MISC) } \\
\mathrm{M} \pm \mathrm{m}\end{array}$ & $\begin{array}{c}\text { Right bank } \\
\mathrm{M} \pm \mathrm{m}\end{array}$ & $\begin{array}{c}\text { Left bank (MISC) } \\
\mathrm{M} \pm \mathrm{m}\end{array}$ \\
\hline $\begin{array}{c}\text { Anxiety (points) } \\
\begin{array}{c}\text { Vegetative balance } \\
\text { (Shiposh coefficient), units }\end{array}\end{array}$ & $3.8 \pm 0.3$ & $3.4 \pm 0.3$ & $3.3 \pm 0.6$ & $4.0 \pm 0.9$ \\
\hline
\end{tabular}

for conclusion about present state of health and future prognosis of diseases development.

It is described that ergotropic domination (dominance of the ANS sympathetic department), is associated with increased mobility and the desire to spent energy, but trophotropic reaction (domination of ANS parasympathetic department), associated with reduced physical activity and the quest for peace (Andreeva, 1994; Asratyan, 1948; Steckler, 2010; Fink, 2019). Ergotropic domination (sympathetic tone) is characterized by physiological parameters closer to normal in comparison with parasympathetic, what means higher adaptive capabilities of the organism of mobile children (Andreeva, 1994; Asratyan, 1948; Steckler, 2010; Fink, 2016).

We tried to supplement this observation with the effects of genome instability. So, our next question concerned the probability of associations between ANS departments work consistency and indicators of children's genomic instability, detected in cultivated blood lymphocytes. The correlative analysis found out the weak but significant negative correlations between Shiposh' coefficient and the expression of cellular division asymmetry (Figure 4) and positive ones between frequencies of binuclear cells in spectrum of cellular division for each child (Figure 5).

3-nuclear cells result from asymmetric chromosome distribution in mitosis and, therefore, are markers of serious chromosomal rearrangements associated with aneuploidy. For the first time, the phenomenon of aneuploidy was detected in tumor cells.

In the spectrum of the populations of dividing cells, the binuclear cells usually present the main fraction, which size can give the information characteristics the cell cycle duration as well as speed of cellular division. An increasing of number of cells in this population allow concluding the deceleration of the division, because it means that the number of cells in other fractions, containing more numbers of nucleus and, consequently, divided more times that binuclear cells, become lower.

Interesting that this result as well as any other significant correlations, found out in this study, observed only in the cohort of children living around the metallurgic combine. The simplest hypothesis about negative action of the 


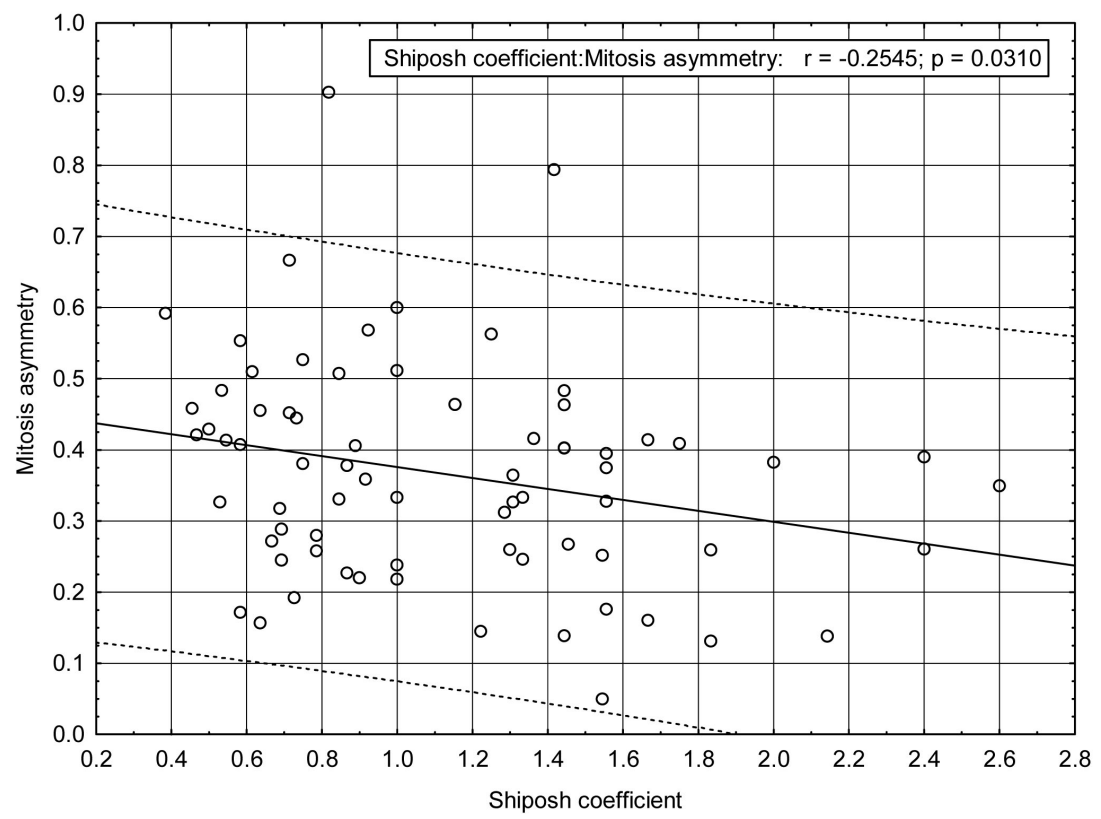

Figure 4. Correlations between Shiposh' coefficient and asymmetry of mitosis (\% of 3-nuclear cells among all divided during 2-nd mitosis) in blood lymphocytes of children living around MISC.

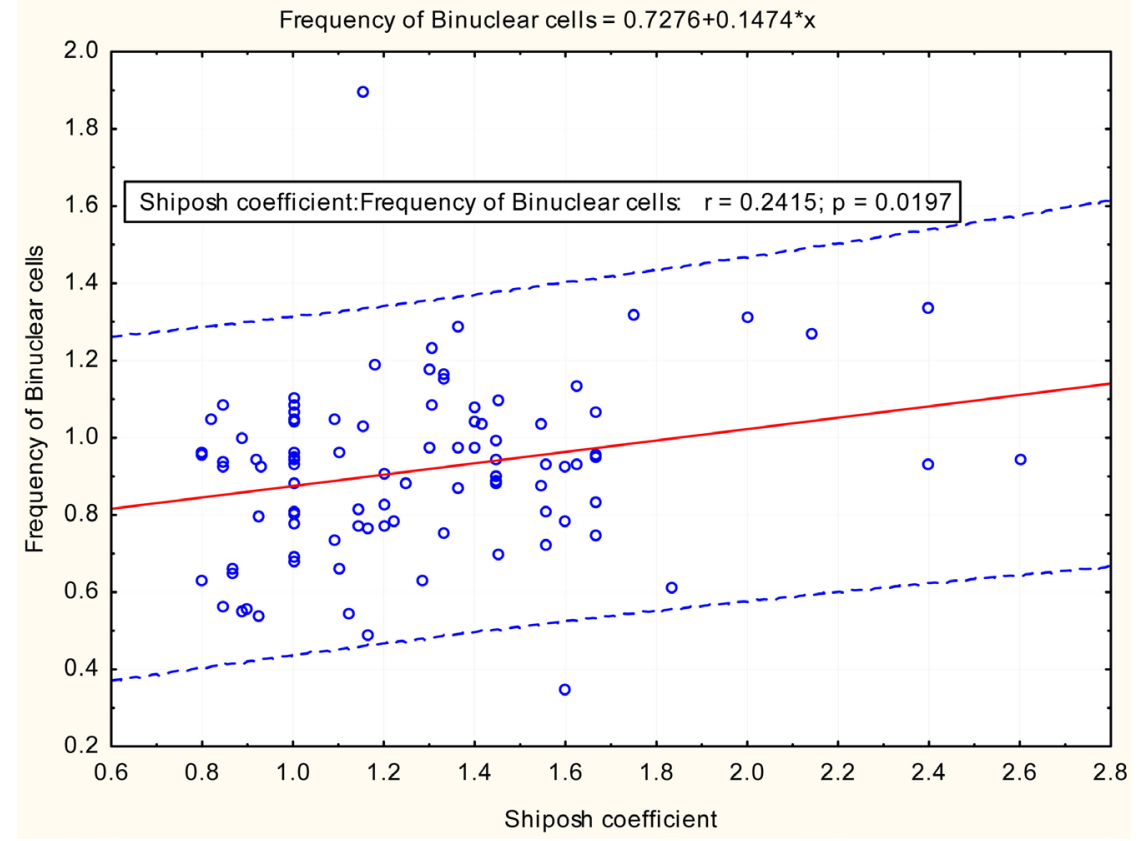

Figure 5. Correlations between Shiposh' coefficient and binuclear cells frequencies in blood lymphocytes of children living around metallurgic combine.

MISC-induced emission have to be rejected because of the results of chemical analysis of air and snow pollution which demonstrated no differences between samples collected in the 2 districts of the city (Ural'shin, 2007). Now we have no answer to the question about the reason of this phenomenon. But, the presented results allow supposing that children with both trophotropic and ergotrophic 
domination may have a higher risk of the diseases associated with genomic instability in comparison with ones living in vegetative balance. For verification of this hypothesis, firstly, we analyzed spectrum of dividing cells-frequencies of cells with 2, 3, 4 and more nuclei (Figure 2). By these indices we did not detect any distinction between children with different types of vegetative balance both spontaneously and under the impact of MNNG.

At the same time, some distinctions in the other indices of genomic instability between children in different types of vegetative balance were detected (Table 2).

As it is seeing on this table, we saw several statistically significant effects, but it was no any regularity in appearance of lower or higher levels of genomic instability among children with sympathetic or parasympathetic domination. Next, we analyzed the MNNG-induced effects in association with children's with the balance of the ANS departments (Table 3).

Table 2. Differences between background level of genomic instability in cultivated blood lymphocytes depending on type of children's vegetative balance. All examined children. Mann-Whitney criterion.

\begin{tabular}{|c|c|c|c|c|c|c|c|}
\hline \multirow[b]{2}{*}{ Index } & \multirow[b]{2}{*}{$\begin{array}{l}\text { Shiposh' } \\
\text { coefficient }\end{array}$} & \multirow[b]{2}{*}{$\begin{array}{c}\text { Apoptosis, } \\
\%\end{array}$} & \multirow{2}{*}{$\begin{array}{c}\text { Undivided cells } \\
\text { 1-nuclear } \\
\text { cells with } \\
\text { protrusions, \% }\end{array}$} & \multirow{2}{*}{$\begin{array}{c}\text { Cells after 1-st mitosis } \\
\text { 2-nuclear } \\
\text { cells with genetic } \\
\text { damage }\end{array}$} & \multicolumn{3}{|c|}{ Cells after 2-nd mitosis } \\
\hline & & & & & $\begin{array}{l}\text { 3-nuclear } \\
\text { cells, } \%\end{array}$ & $\begin{array}{l}\text { 3-nuclear } \\
\text { cells with } \\
\text { genetic damage }\end{array}$ & $\begin{array}{c}\text { 4-nuclear } \\
\text { cells with } \\
\text { genetic damage }\end{array}$ \\
\hline $\begin{array}{l}\text { Parasympathetic } \\
\text { domination }\end{array}$ & $0.60^{*}$ & $1.02^{*}$ & 0.20 & $0.89 \# .^{*}$ & $6.20 \#$ & $9.61 \#$ & $9.15 \#$ \\
\hline StMistake & 0.02 & 0.18 & 0.06 & 0.12 & 0.39 & 1.41 & 1.32 \\
\hline Balance (norm) & 0.99 & 1.15 & 0.34 & 1.15 & 5.90 & 8.82 & 9.22 \\
\hline StMistake & 0.02 & 0.14 & 0.07 & 0.14 & 0.36 & 1.11 & 1.47 \\
\hline $\begin{array}{l}\text { Sympathetic } \\
\text { domination }\end{array}$ & $1.56^{*}$ & $0.99 \&$ & $0.46 \#$ & 0.95 & 5.70 & 11.03 & 7.10 \\
\hline StMistake & 0.04 & 0.14 & 0.08 & 0.12 & 0.38 & 1.55 & 0.75 \\
\hline
\end{tabular}

Note: statistical significance $(\mathrm{p}<0.05)$; $\left(^{*}\right)$ differences between the state of balance (norm) and trophotropic domination; $(\#)$ differences between trophotropic and ergotropic domination; (\&) differences between ergotropic domination and the state of balance (norm).

Table 3. In vitro sensitivity of children's blood cultures to standard mutagen action. All children examined. Mann-Whithey criterion.

\begin{tabular}{|c|c|c|c|c|c|}
\hline & $\begin{array}{l}\text { Shiposh' } \\
\text { coefficient }\end{array}$ & $\begin{array}{l}\text { 2-nuclear cells in the } \\
\text { spectrum of divided cells, \% }\end{array}$ & $\begin{array}{l}\text { 2-nuclear cells } \\
\text { with MN, \% }\end{array}$ & $\begin{array}{l}\text { 3-nuclear } \\
\text { cells with NB, \% }\end{array}$ & $\begin{array}{l}\text { Quickly divided }{ }^{1} \\
\text { cells among divided, } \%\end{array}$ \\
\hline $\begin{array}{l}\text { Parasympathetic } \\
\text { domination }\end{array}$ & $0.60^{*}$ & 0.88 & $2.19^{*}$ & $1.88^{\star} \&$ & 0.63 \\
\hline StMistake & 0.02 & 0.02 & 0.26 & 0.31 & 0.03 \\
\hline Balance (norm) & 0.99 & 0.87 & 1.68 & 3.04 & 0.65 \\
\hline StMistake & 0.02 & 0.03 & 0.23 & 0.29 & 0.03 \\
\hline $\begin{array}{l}\text { Sympathetic } \\
\text { domination }\end{array}$ & $1.56^{*}$ & $0.96 \# \&$ & 1.88 & $1.73 \&$ & $0.56 \#$ \\
\hline StMistake & 0.04 & 0.03 & 0.28 & 0.17 & 0.03 \\
\hline
\end{tabular}

Note: statistical significance $(\mathrm{p}<0.05)$; $\left({ }^{*}\right)$ differences between the state of balance (norm) and trophotropic domination; (\#) differences between trophotropic and ergotropic domination; (\&) differences between ergotropic domination and the state of balance (norm).

${ }^{1}$ Quickly divided cells have more than 2 nuclei. 
In both cases, it is impossible to formulate any correct conclusion concerning regularity of the cytogenetic effects of any domination varied from the norm, too. But the obtained data (Table 3 and Table 4) demonstrated that the effects exist in reality-practically all main indices of genomic instability differed significantly from the data, obtained for children, living in state of vegetative balance (norm). This conclusion is very important because allow create the new point of view to the biological consequences of the ANS departments misbalance and elaborate the new direction of the study.

The next direction of the study aimed to identify the relationship between severity of children anxiety and the effects of genome instability in their blood cultures (the generalized results are present in Table 4).

\section{Conclusion}

In this article, we demonstrated some previously unpublished results of healthy children of middle and senior preschool age investigation. These children permanently lived in the two districts of Magnitogorsk-around the metallurgical combine and on the other bank of the Ural River.

Our work showed that these cohorts of children are characterized by fundamentally different psychosomatic properties associated with the differences of anxiety level and with unbalanced work of the autonomic nervous system departments (autonomic tone). Here for the first time we demonstrated that these psychosomatic characteristics are associated with spontaneous effects of genome instability and individual sensitivity to small in vitro genotoxic load with standard mutagen MNNG. Although in this article we did not understand the regularities of these changes and could not identify the main laws of the relationship between the type of vegetative tone and genotoxic effects as well as individual sensitivity of genome to low genotoxic load, we have shown that such associations exist.

These data are very important because they for the first time demonstrate that people, and, above all, children living in a state of unbalanced work of the departments of the autonomic nervous system, are in risk zone of developing diseases associated with an increased level of genome instability. It is especially important to identify such people in advance among living in the state of increased and high emotional stress (anxiety, for example).

Table 4. The differences between children with distinct levels of anxiety expression.

\begin{tabular}{ccccc}
\hline Index & & Mitosis & $\begin{array}{c}\text { \% of rapidly dividing cells in the } \\
\text { spectrum of cellular populations }\end{array}$ & $\begin{array}{c}\text { \% of rapidly dividing } \\
\text { cells with MN }\end{array}$ \\
\hline \multirow{2}{*}{ Norm } & Average & $3.73^{*}$ & 24.4 & $4.34^{*}$ \\
& StMistake & 0.12 & 0.67 & 0.29 \\
\multirow{3}{*}{ High } & Average & 4.01 & 27.9 & 5.65 \\
& StMistake & 0.36 & 2.06 & 0.95
\end{tabular}

*the differences between children in high and norm levels of anxiety are statistical significant, $\mathrm{p}<0.05$. 


\section{Acknowledgements}

The authors are sincerely grateful to E. M. Vinogradova-the Deputy Head of the Health Department of Magnitogorsk, for their help in organizing the survey.

\section{Conflicts of Interest}

The authors declare no conflicts of interest regarding the publication of this paper.

\section{References}

Alexander, F. (1950). Psychosomatic Medicine. New York: Norton Company.

Andreeva, A. (1994). Cognitive and Personal Characteristics of Children in a Large Family. PhD Thesis. (In Russian)

Antipanova, N. A., \& Koshkina, V. S. (2007). Ecological Conditionality of Oncological Morbidity of the Population of the Industrial Center of Ferrous Metallurgy. Human Ecology, 3, 9-13.

Asratyan, E. A. (1948). About an Adaptive Reactions in a Damaged Organism. Transcript of a Public Lecture, Moscow: Pravda. (In Russian)

Bergholz, L. M., Subic-Wrana, C., Heylmann, D., Beutel, M. E., Wiltink, J., \& Kaina, B. (2017). DNA Damage in Lymphocytes of Patients Suffering from Complex Traumatization. DNA Repair, 52, 103-109. https://doi.org/10.1016/j.dnarep.2017.02.006

Bolognesi, C., \& Fenech, M. (2019). Micronucleus Cytome Assays in Human Lymphocytes and Buccal Cells. Methods in Molecular Biology, 2031, 147-163.

https://doi.org/10.1007/978-1-4939-9646-9_8

Dragunsky, V. V. (2004). Color Personality Test. Practical Guide. Moscow: Harvest. (In Russian)

Fink, G. (2016). Stress: Concepts, Cognition, Emotion, and Behavior: Handbook in Stress Series, Volume 1. Cambridge, MA: Academic Press.

Fink, G. (2019). Stress: Physiology, Biochemistry, and Pathology: Handbook of Stress Series, Volume 3. Cambridge, MA: Academic Press.

Ingel, F. I. (2006). Perspectives of Micronuclear Test in Human Lymphocytes Cultivated in Cytogenetic Block Conditions. Part 1: Cell Proliferation. Ecologichescaa Genetica, 4, 7-19. (In Russian) http://ecologenet.ru/ru/system/files/2006_4_38-54.pdf https://doi.org/10.17816/ecogen437-19

Ingel, F. I. (2006). Perspectives of Micronuclear Test in Human Lymphocytes Cultivated under Cytogenetic Block Conditions. Part 2. Environmental Factors and Individual Features in System of Evaluation of Human Genome Instability. Additional Capability of the Test. The Technique for Cytogenetic Analysis. Ecologichescaa Genetica, 4, 38-53. (In Russian) http://ecolgenet.ru/ru/system/files/2006_3_7-19.pdf

Ingel, F. I., Legostaeva, T. B., Antipanova, N. A., Yurchenko, V. V., Urtseva, N. A., \& Kotlyar, N. N. (2010). Hygienic Study of Total Mutagenic Activity of Magnitogorsk Snow Samples. Gig Sanit, 4, 47-52. (In Russian)

Ingel, F., Krivtsova, E., Urtseva, N., \& Legostaeva, T. (2018). Children's, Adult's and Family's Emotional Stress in Context of Genomic Instability. Open Journal of Social Sciences, 6, 48-65. http://www.scirp.org/journal/jss https://doi.org/10.4236/jss.2018.66005

Markkanen, E., Meyer, U., \& Dianov, G. L. (2016). DNA Damage and Repair in Schi- 
zophrenia and Autism: Implications for Cancer Comorbidity and Beyond. International Journal of Molecular Sciences, 17, pii: E856. https://doi.org/10.3390/ijms17060856

Nersesyan, A., Fenech, M., Bolognesi, C., Mišík, M., Setayesh, T., Wultsch, G., Bonassi, S. et al. (2016). Use of the Lymphocyte Cytokinesis-Block Micronucleus Assay in Occupational Biomonitoring of Genome Damage Caused by in Vivo Exposure to Chemical Genotoxins: Past, Present and Future. Mutation Research, 770, 1-11. https://doi.org/10.1016/j.mrrev.2016.05.003

Pocock, G. (2006). Human Physiology (3rd ed.). Oxford: Oxford University Press.

Seredenin, S. V., Durnev, A. D., \& Vedernikov, A. A. (1980). Influence of Emotional Stress on the Frequency of Chromosomal Aberrations in Mice Bone Marrow Cells. Bulletin of Experimental Biology and Medicine, 7, 91-92. (In Russian) https://doi.org/10.1007/BF00833277

Slamenová, D., Horváthová, E., Robichová, S., Hrusovská, L., Gábelová, A., Kleibl, K., Jakubíková, J., \& Sedlák, J. (2003). Molecular and Cellular Influences of Butylated Hydroxyanisole on Chinese Hamster V79 Cells Treated with N-methyl-N'-nitro-N-nitrosoguanidine: Antimutagenicity of Butylated Hydroxyanisole. Environmental and Molecular Mutagenesis, 41, 28-36. https://doi.org/10.1002/em.10127

Smith, L. E., Nagar, S., Kim, G. J., \& Morgan, W. F. (2003). Radiation-Induced Genomic Instability: Radiation Quality and Dose Response. Health Physics, 85, 23-29. https://doi.org/10.1097/00004032-200307000-00006

Sobchik, L. N. (2003). Method of Color Choices. Modification of the Eight-Color M. Luscher's Test. (In Russian)

Steckler, Th. (2010). Handbook of Stress and the Brain Part 2: Stress: Integrative and Clinical Aspects. Amsterdam: Elsevier Science.

Ural'shin, A. G., Gavrilov, A. P., Brylina, N. A., Nikiforova, E. V., Beketov, A. L., Sychev, I. A., Menukhov, A. E. et al. (2007). Inhalation Risk upon Exposure to Emission from Industrial Enterprises in Magnitogorsk Town. Gig Sanit, 3, 15-18. (In Russian)

Veenstra, G., Luginaah, I., Wakefield, S. et al. (2005). Who You Know, Where You Live: Social Capital, Neighbourhood and Health. Social Science and Medicine, 60, 799-818. https://doi.org/10.1016/j.socscimed.2004.11.013

Wein, A. M. (1998). Autonomic Disorders. Clinic Diagnostics. Treatment. Moscow: Medical Informational Agency. (In Russian)

WMA Declaration of Helsinki-Ethical Principles for Medical Research Involving Human Subjects (1964-2008).

https://www.wma.net/policies-post/wma-declaration-of-helsinki-ethical-principles-formedical-research-involving-human-subjects

Zlobina, O. Yu., Shinkarenko, V. S., \& Maslova, E. S. (2004). Psychovegetative Syndrome in the Structure of Autonomic Disorders in Patients of Outpatient Network. Successes of Modern Matural Science, 2, 54-55. (In Russian) 


\section{Abbreviations and Acronyms}

MN-Micronucleus is the name given to the small nucleus that forms whenever a chromosome or a fragment of a chromosome is not incorporated into one of the daughter nuclei during cell division. It usually is a sign of genotoxic events and chromosomal instability. Micronuclei are commonly seen in cancerous cells and may indicate genomic damage events that can increase the risk of developmental or degenerative diseases. Micronuclei form during anaphase from lagging acentric chromosome or chromatid fragments caused by incorrectly repaired or unrepaired DNA breaks or by nondisjunction of chromosomes. This incorrect segregation of chromosomes may result from hypomethylation of repeat sequences present in pericentromeric DNA, irregularities in kinetochore proteins or their assembly, dysfunctional spindle apparatus, or flawed anaphase checkpoint genes. Many micronucleus assays have been developed to test for the presence of these structures and determine their frequency in cells exposed to certain chemicals or subjected to stressful conditions [6] [12] [16].

NB-Nucleoplasmic bridges will occur when centromeres of dicentric chromosomes are pulled to opposite poles of the cell during the anaphase. During the formation of two new nuclei of daughter cells in the telophase, the formed nucleoplasmic bridge also becomes covered with a nuclear envelop. 